\title{
Comparative Strength Analysis of Normal Weight and Palm Kernel Shell Reinforced Concrete Beams for Sustainable Development
}

\author{
Lekan Makanju Olanitori ${ }^{1}$ and Jeremiah Ibukun Okusami ${ }^{2}$
}

\begin{abstract}
Reduction in self-weight of Palm Kernel Shell Concrete (PKSC) over Normal Weight Concrete (NWC), reduces the amount of cement needed for construction, this is accompanied by reduction in $\mathrm{CO}_{2}$ emission associated with the production of cement: This will have reduction effect on the greenhouse, a major cause of climate change. This study carries out the comparative analysis of the strength characteristics of NWC and PKSC beams produced from four concrete mixes of $0 \%, 20 \%$, $40 \%$ and $60 \%$ partial replacement of crushed granite by palm kernel shell (PKS). From each concrete mix, two beams were cast: one with shear reinforcement of $200 \mathrm{~mm}$ spacing, while the other one without shear reinforcement, making total of eight beams. From the study, the PKS concrete beams were $3.6 \%, 11.24 \%$ and $15.64 \%$ lighter than the NWC beams for $20 \%, 40 \%$ and $60 \%$ partial PKS replacement. The study shows that reinforced concrete beams produced from $20 \%$ and $40 \%$ partial replacement of crushed aggregate by PKS have the potential of being used for structural purposes in low cost buildings.
\end{abstract}

Keywords: Palm Kernel Shell Concrete, Normal weight concrete, Palm kernel shell, Strength characteristic, Cement.

\section{Introduction}

The use of conventional natural materials, drastically reduce the natural stone deposit and this has damaging effect on the environment causing ecological imbalance (Short and kinniburgh, 1998; Alengaram et al., 2008). Therefore the need to explore/investigate other forms of coarse aggregate to reduce the construction cost and preserve our natural deposits for sustainable development. Also, reduction in self-weight of Light Weight Concrete (LWC) over Normal Weight Concrete (NWC) translates to reduction in the sizes of structural members of reinforced concrete structures, which in turn, reduces the amount of cement needed for construction, this is accompanied by reduction in $\mathrm{CO}_{2}$ emission associated with the production of cement: This have reduction effect on the greenhouse, a major cause of climate change.

Presently, agricultural wastes constitute major waste management and pollution problem, therefore the use of agricultural and industrial wastes in construction will help to reduce pollution. In his work, Abdullah, concluded that agricultural waste have advantages over conventional materials in low cost construction (1996). It was also noted that the use of waste materials in construction contribute to conservation of natural resource and the protection of our environment (Osei and Jackson, 2012). The palm 
kernel shell (PKS) is one of such agricultural produce that has caused management problem in some parts of the world.

From literature, many researches have been conducted on the possibility of using agricultural waste ashes as partial replacement for cement in the construction industry. Researches have been carried out on partial replacement of cement with Bamboo Leaf Ash (Dwiveldi et al., 2006), partial replacement of cement with Rice Husk Ash (Chungsangunsit et al., 2007), partial replacement of cement with Palm Fruit Ash (Olonode, 2010), partial replacement of cement with Locust Bean Pod Ash (Adama and Jimoh, 2011), partial replacement of cement with Cassava Peel Ash (Salau et al., 2012), partial replacement of cement with Corn Husk Ash (Adesanya and Raheem, 2009) and partial replacement of cement with Corn Cob Ash (Akinwumi and Aidomojie, 2015; Yinusa and Jimoh, 2014). Also Busari, et al., (2018) carried out research on the possibility of using Bamboo Straw Ash to improve the Index Properties of Lateritic Soil. Also, some researches have been carried out on partial replacement of normal weight aggregate with Oil-Palm-Boiler Clinker (Chai, et al., 2017) and partial replacement of normal weight aggregate with Oil Palm Shell (Aslam, et al., 2017).

The hard nature of palm kernel shell (PKS) has given it a great potential to be used as coarse aggregate in concrete, especially in the production of lightweight concrete. From literatures PKS when properly processed have shown to be effective as a construction material, however in the construction industry in Nigeria, the use of palm kernel shell as coarse aggregate are not common, which is due to lack of information on the potential of PKS to be used as coarse aggregate (Ndoke, 2006).

Light Weight Aggregate concrete is not a new invention in concrete technology; it has been used since ancient times (Shafigh et al., 2012). The use of palm kernel shell as replacement for coarse aggregate can be termed light Weight Concreting (LWC) if the density of concrete produced from such aggregates falls between $1200 \mathrm{~kg} / \mathrm{m}^{3}$ and 2000 $\mathrm{kg} / \mathrm{m}^{3}$, while the use of the conventional aggregate can be termed Normal weight Concreting (NWC), since the density of the concrete produced from them is the range of $2000 \mathrm{~kg} / \mathrm{m}^{3}$ to $2500 \mathrm{~kg}$ (Newman and Owen, 2003). The light weight concreting has great advantage of the reduction in the dead weight of a building. For small building units, the savings thus achieved may not be significant. But for multiple building units (as the case in an estate), any saving due to reduction in structural member sizes multiplied by the number of building units can represent a substantial saving in total construction cost of the building units. Hence, the present study therefore investigates the strength characteristic of slender reinforced concrete beams, with shear reinforcement spacing of $200 \mathrm{~mm}$, produced from 20\%, 40\% and 60\% partial replacement of Normal Weight Aggregate (NWA) with Palm Kernel Shell Aggregate (PKSA) for structural application in low cost housing construction.

\section{Methodology}

The PKS which was used for this study was obtained from a palm kernel oil production site along Ondo Road, Akure Nigeria. The PKS, were washed with detergent and flushed with portable water (warm) to remove dirt, oil film coating and other impurities which could be detrimental to the concrete. The maximum size of the PKS 
was $19 \mathrm{~mm}$, while that of the coarse aggregate (crushed granite) was $12 \mathrm{~mm}$. The maximum size of the sand used was $5 \mathrm{~mm}$.

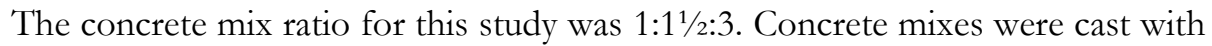
varying percentages of PKS for the partial replacement of crushed granite at $0 \%, 20 \%$, $40 \%, 60 \%, 80 \%$ and $100 \%$ respectively. The compressive test was carried out according to BS EN 12390-3 (2009), while the slump test was carried out according to BS EN 12350-2 (2009), to determine the workability of concrete. Concrete density was determined according to BS EN 12390-7 (2000). NWC (control cubes) and PKSC (partially replaced cubes) of $150 \times 150 \times 150 \mathrm{~mm}$, were then water-cured and its characteristic strengths determined at $7^{\text {th }}, 14^{\text {th }}, 21^{\text {st }}$ and $28^{\text {th }}$ days respectively.

\subsection{Experimental Beam Details}

Table 1shows the reinforcement details for the beam types, while cross section of the beams is shown in Figures 1 and 2. Two type of beams were designed for testing: beam without shear reinforcement (W) and beam with shear reinforcement (S).

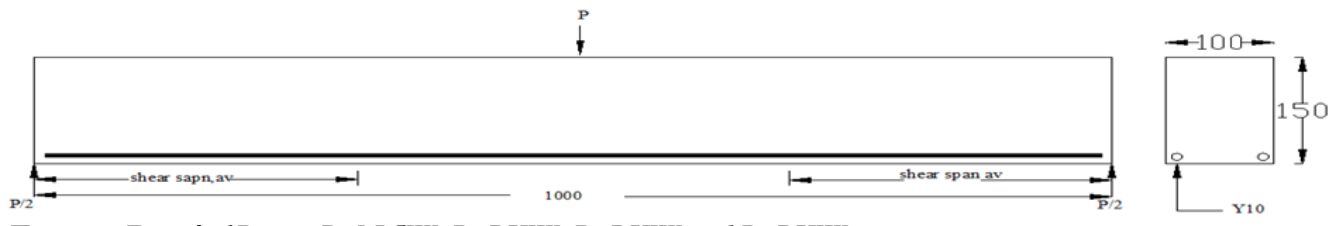

Figure 1: Detail of Beams B1NCW, B3PKW, B5PKW and B7PKW

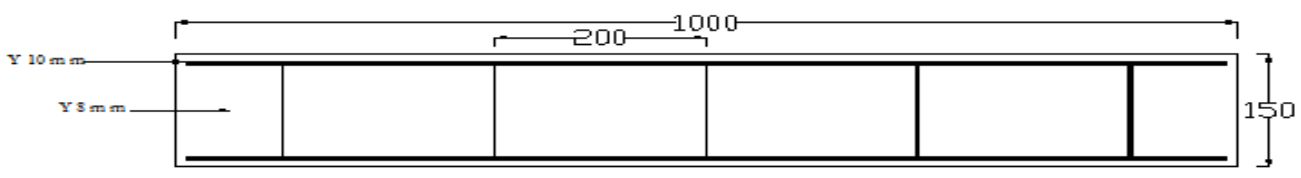

Figure 2: Detail of Beams B2NCW, B4PKW, B6PKW and B8PKW

Table 1: Beams detail

\begin{tabular}{|c|c|c|c|c|c|}
\hline Beam ID & $\mathbf{b}$ & h & Length & Shear Reinf. Spacing & Bottom/top/links Reinforcement \\
\hline & $(\mathrm{mm})$ & $(\mathrm{mm})$ & & $(\mathrm{mm})$ & \\
\hline \multicolumn{6}{|c|}{ Beam with $0 \%$ PKSA replacement of NWA } \\
\hline $\mathrm{B} 1_{\mathrm{NCW}}$ & 100 & 150 & 100 & - & Y10 B \\
\hline $\mathrm{B} 2_{\mathrm{NCS}}$ & 100 & 150 & 100 & 200 & Y10B/T, Y8L \\
\hline \multicolumn{6}{|c|}{ Beam with $20 \%$ PKSA replacement of NWA } \\
\hline $\mathrm{B} 3_{\mathrm{PKW}}$ & 100 & 150 & 100 & - & Y10 B \\
\hline B4 PKS & 100 & 150 & 100 & 200 & $\mathrm{Y10B} / \mathrm{T}, \mathrm{Y} 8 \mathrm{~L}$ \\
\hline \multicolumn{6}{|c|}{ Beam with $40 \%$ PKSA replacement of NWA } \\
\hline B5 PKW & 100 & 150 & 100 & - & Y10 B \\
\hline B6 PKS & 100 & 150 & 100 & 200 & Y10B/T, Y8L \\
\hline \multicolumn{6}{|c|}{ Beam with $60 \%$ PKSA replacement of NWA } \\
\hline B7PKW & 100 & 150 & 100 & - & Y10 B \\
\hline B8 PKS & 100 & 150 & 100 & 200 & $\mathrm{Y10B} / \mathrm{T}, \mathrm{Y} 8 \mathrm{~L}$ \\
\hline
\end{tabular}

Where:

$\mathrm{b}$ and $\mathrm{h}$ are breadth and height respectively. 
$\mathrm{B} 1_{\mathrm{NCW}}$ - beam from NWC without shear reinforcements.

B2 $2_{\text {NCS }}$ - beam from NWC with shear reinforcements at $200 \mathrm{~mm}$ spacing.

$\mathrm{B} 3{ }_{\mathrm{PKW}}, \mathrm{B} 5 \mathrm{PKW}_{\mathrm{PW}}$ and $\mathrm{B} 72_{\mathrm{PKW}}$ are beams from PKS without shear reinforcements.

B4 $4_{\mathrm{PKS}}, \mathrm{B} 6 \mathrm{PKS}$ and B82 $\mathrm{PKS}$ are beams from PKS with shear reinforcements at $200 \mathrm{~mm}$ spacing.

\subsection{Test procedure}

The beams were subjected to flexural tests, using Flexural Testing Machine with $300 \mathrm{kN}$ capacity. The beams were subjected to a point load at beams centre, with effective length of $750 \mathrm{~mm}$. The flexural tests were carried out in accordance with BS EN 12390-5 (2009). The beams were loaded until collapse occurred.

\section{Result and Discussion}

The results of the tests carried out on aggregate, cement, fresh and hardened concrete is presented below.

\subsection{Aggregate}

From Figure 3, the coefficients of uniformity $\left(\mathrm{C}_{\mathrm{u}}\right)$ of sand was determined to be 1.4 and while the coefficient of gradation $\left(C_{c}\right)$ was determine to be 2.93 . Since $C_{u}$ is less than 4 and $C_{c}$ is greater than 1 but less than 3 , the fine aggregate is said to be wellgraded. Table 2 gives the physical properties of the materials used in concrete.

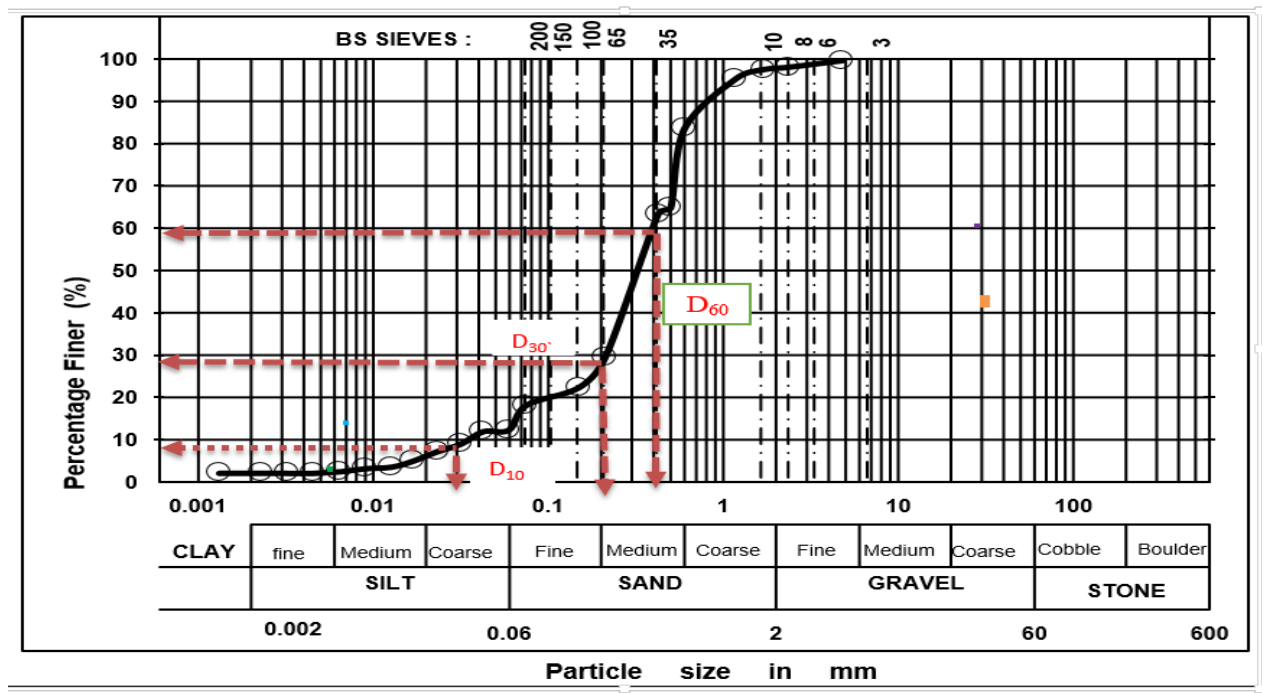

Figure 3: Particle Size Distribution of Fine Aggregate.

\subsection{Cement}

The cement type used in this study was Ordinary Portland cement of grade 32.5 conforming to BS EN 197-1 (2000). Some physical properties of the cement used are presented in Table 3. 
Table 2: The experimental physical properties of aggregate

\begin{tabular}{|l|c|c|c|}
\hline Properties & PKS & Granite & Sand \\
\hline Maximum aggregate size(mm) & 19 & 12 & 5 \\
Shell thickness, mm & $1-5.9$ & 0 & \\
Specific gravity, saturated surface dry & 1.33 & 2.65 & 2.60 \\
Aggregate impact value (AIV) & 7.6 & 22.9 & \\
Aggregate crushing value (ACV) & 16.8 & 30.1 & \\
24hour water absorption & 18 & 0.68 & \\
Moisture content & 9.7 & 0 & $7 \%$ \\
uniformity coefficient $\mathbf{C}_{\mathbf{u}}$ & & & 1.4 \\
coefficient of gradation $\mathbf{C c}$ & & & 2.93 \\
\hline
\end{tabular}

Table 3: Test on Portland cement

\begin{tabular}{|l|c|}
\hline Test & Average \\
\hline Fineness Test (\%) & 2.2 \\
Soundness (mm) & 0.25 \\
Initial Setting Time & $30 \mathrm{~min}$ \\
Final Setting Time & $9 \mathrm{hr} 18 \mathrm{~min}$ \\
\hline
\end{tabular}

\subsection{Reinforcement properties}

The result of the tests carried out on the steel reinforcement used in this study is presented in Table 4.

Table 4: Strength of tested reinforcement

\begin{tabular}{|c|c|c|c|}
\hline \multirow{2}{*}{$\begin{array}{c}\text { Reinforcement Bars Size } \\
(\mathbf{m m})\end{array}$} & \multicolumn{3}{|c|}{ Yield Stress $\mathbf{( N / \mathbf { m m } ^ { 2 } )}$} \\
\cline { 2 - 4 } & Bar 1 & Bar 2 & Average \\
\hline Y8 & 460 & 480 & 470 \\
Y10 & 500 & 460 & 480 \\
\hline
\end{tabular}

\subsection{Tests on fresh concrete}

The results of the slump test, indicating the workability of the concrete at $0 \%$, $20 \%, 40 \%, 60 \%, 80 \%$, and $100 \%$ replacement of NWA with PKSA are presented in Table 5.

Table 5. Concrete mix proportion for PKS replacement with coarse aggregate.

\begin{tabular}{|c|c|c|c|c|c|c|c|c|c|}
\hline $\begin{array}{c}\text { PR } \\
\mathbf{( \% )}\end{array}$ & $\begin{array}{c}\text { Cement } \\
\mathbf{k g}\end{array}$ & $\mathbf{w} / \mathbf{c}$ & $\begin{array}{c}\text { PKS } \\
\text { Vol. }\end{array}$ & $\begin{array}{c}\text { NWA } \\
\mathbf{k g}\end{array}$ & $\begin{array}{c}\mathbf{F N} \\
\mathbf{( k g})\end{array}$ & $\begin{array}{c}\mathbf{S V} \\
\mathbf{( m m})\end{array}$ & $\begin{array}{c}\text { Type } \\
\text { of slump }\end{array}$ & Degree of workability & $\begin{array}{c}\text { Compaction } \\
\text { factor }\end{array}$ \\
\hline $\mathbf{0}$ & 331 & 0.6 & 0 & 800 & 552 & 66 & TS & medium & 0.91 \\
$\mathbf{2 0 \%}$ & 331 & 0.6 & 160 & 640 & 552 & 60 & TS & medium & 0.89 \\
$\mathbf{4 0 \%}$ & 331 & 0.6 & 320 & 480 & 552 & 55 & TS & medium & 0.87 \\
$\mathbf{6 0 \%}$ & 331 & 0.6 & 480 & 320 & 552 & 50 & TS & medium & 0.83 \\
$\mathbf{8 0 \%}$ & 331 & 0.6 & 640 & 160 & 552 & 48 & TS & low & 0.79 \\
$\mathbf{1 0 0 \%}$ & 331 & 0.6 & 800 & 0 & 552 & 39 & TS & low & 0.77 \\
\hline
\end{tabular}

From Table 5 and Figure 4, all the Specimens showed true slump, this could be as a result of the high water-cement ratio of 0.6 used for the mix proportion all through the research. It can however be seen ( Figure 4 ), that the slump decreased as the percentage of the PKS in the mix increased as a result of high water absorption by the PKS. This trend of reduction was also repeated in the compacting factor test (Table 5). 


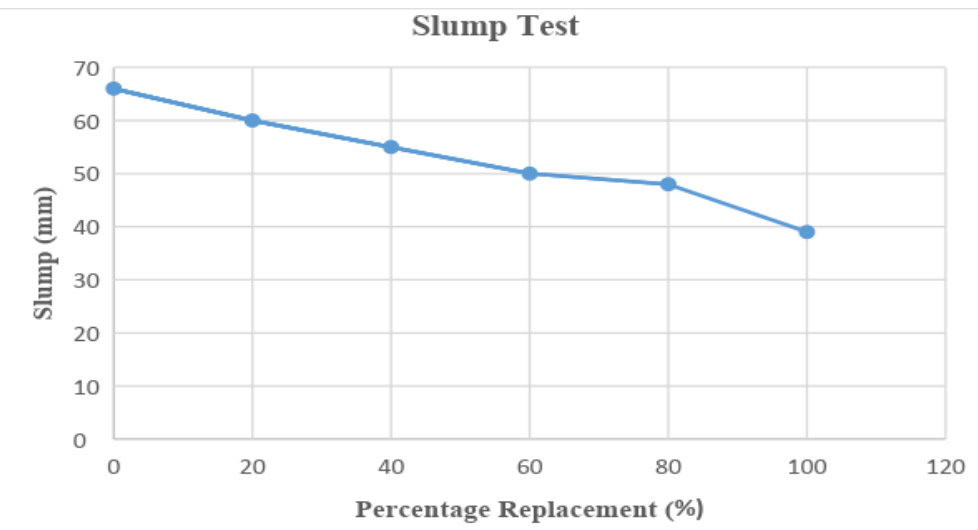

Figure 4: Slump test against percentage replacement

The compacting factor values between 0.80 and 0.90 obtained for the specimens suggested a concrete with medium to low workability (Neville, 1981). From Table 5, it can also be seen that $80 \%$ and $100 \%$ replacement showed low degree of workability, this occurred because the mix became harsh as a result of a high water absorption rate of the PKSA.

\subsection{Tests on hardened concrete}

\subsubsection{Density}

The relationship between densities of the NWC and the PKSC are presented in Table 6. From Table 6, based on the concrete density, concrete with $0 \%, 20 \%, 40 \%$ and $60 \%$ of partial replacement of NWA with PKSA can be classified NWC, while concrete with $80 \%$ and full replacement of NWA with PKSA can be classified as LWC.

Table 6: Experimental Air dry density of PKSC/NWC.

\begin{tabular}{|c|c|c|c|c|c|}
\hline Type of concrete & $\begin{array}{c}\text { Percentage of PKSA } \\
\text { \% }\end{array}$ & \multicolumn{4}{|c|}{ Air dry density of various mix $\mathbf{~ K g} / \mathbf{m}^{\mathbf{3}}$} \\
\cline { 3 - 6 } & 0 & 2083 & 2300 & 2360 & 2500 \\
\hline NWC & 20 & 1993 & 2071 & 2341 & 2410 \\
PKSC & 40 & 1978 & 2056 & 2210 & 2219 \\
PKSC & 60 & 1847 & 2038 & 2080 & 2109 \\
PKSC & 80 & 1782 & 1797 & 1799 & 1830 \\
PKSC & 100 & 1432 & 1438 & 1524 & 1781 \\
PKSC & \multicolumn{4}{|c}{} \\
\hline
\end{tabular}

\subsubsection{Compressive Strength}

The variation of characteristic strengths of concrete with curing age for concrete cubes with percentage replacement of NWA with PKSA at $0 \%, 20 \%, 40 \%, 60 \%, 80 \%$ and $100 \%$ respectively is shown in Figure 5. It can be observed that the characteristic strengths of the specimens increased with the curing age at all the percentage replacement of NWA with PKSA. This indicated an undisturbed strength-forming hydration process. However, the characteristic strength decreased as the amount of palm kernel shell in the concrete increases. The result of characteristic strength of the concrete cubes with age of curing is presented in Table 7. 
Table 7: Summary of Compressive Strength Test Result with Age of curing

\begin{tabular}{|c|c|c|c|c|}
\hline Percentage replacement & 7 day & 14 day & 21 day & 28day \\
\hline & & & $\left(\mathrm{N} / \mathrm{mm}^{2}\right)$ & \\
\hline $0 \%$ & 7.03 & 8.05 & 9.01 & 10.42 \\
\hline $20 \%$ & 6.05 & 6.99 & 7.9 & 8.39 \\
\hline $40 \%$ & 6.0 & 6.74 & 7.49 & 7.44 \\
\hline $60 \%$ & 5.56 & 6.88 & 7.02 & 7.12 \\
\hline $80 \%$ & 5.34 & 5.83 & 5.97 & 5.84 \\
\hline $100 \%$ & 4.16 & 4.49 & 4.47 & 5.00 \\
\hline
\end{tabular}

From Figure 5, it can be seen that the characteristic strength of the control cubes were higher than the characteristic strengths of the concrete cubes with partial replacement of NWA with PKSA. The significant difference between the two types of concrete showed the effect of percentage replacement. The control cubes of NWC were seen to be higher than the PKSC by $19.48 \%, 28.6 \%, 31.7 \%, 43.95 \%$, and $52.02 \%$ for $20 \%, 40 \%, 60 \%, 80 \%$ and $100 \%$ replacement at 28 days of curing respectively. The effect of clay content present in the fine aggregate contributed to the reduced strength of the two types of concrete as both types of concrete did not meet the required specified standard. From the sieve analysis carried out, the percentage of clay in the fine aggregate was $18.26 \%$, this was higher than the maximum percentage of $4 \%$ by weight of sand required by BS 882 to achieve better strength.

\section{Compressive Strength Test}

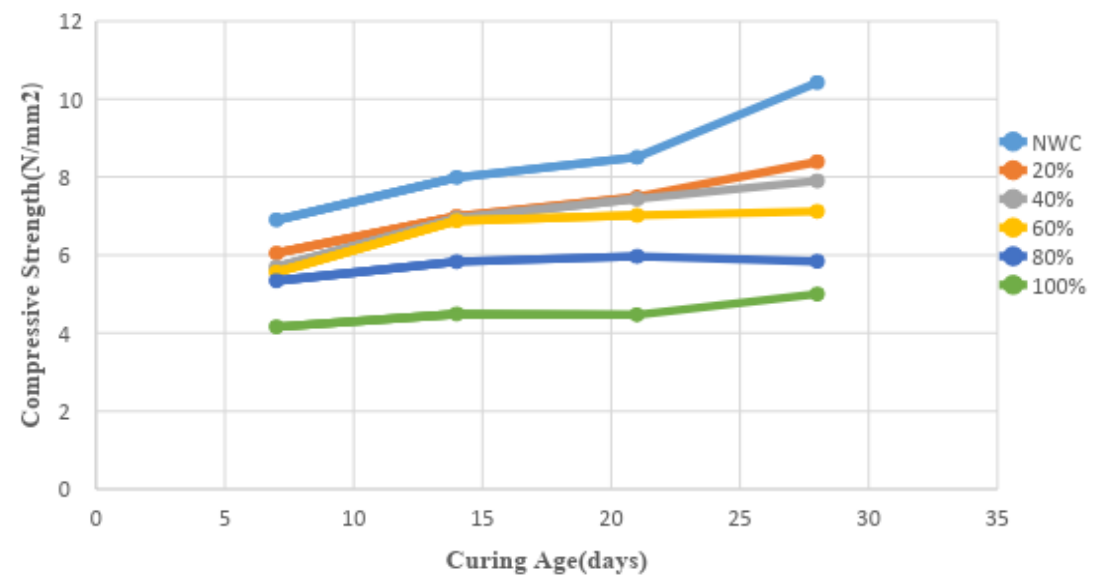

Figure 5: Comparison between the compressive strength of PKSC and NWC

\subsection{Test on beams}

Table 8, presents the results of flexural tests carried out the beams loaded with point load at the centre. The bending stress is given by Eq. 1 .

$$
F_{r}=\frac{3 F L}{2 b d^{2}}
$$

Where; $F=$ is the ultimate load, $L=i$ the beam span, $b=i$ is the breadth and $d=i$ is the depth. 
From Figure 6, the ultimate loads of the NWC beams are higher than that of the PKSC beams. This may be attributed to the higher roughness of the surface of granite aggregates and thus a better aggregate interlock and better bonding of the aggregates with the cement paste than that of PKSA.

Table 8: Experimental load at first crack and failure load

\begin{tabular}{|l|c|c|c|c|c|c|c|}
\hline Type & Shear Spacing & Max Force & Load at First Crack & L & b & d & Flexural capacity(Fr) \\
\hline & $(\mathrm{mm})$ & $\mathrm{kN}$ & $\mathrm{kN}$ & $(\mathrm{mm})$ & $(\mathrm{mm})$ & $(\mathrm{mm})$ & $\left(\mathrm{N} / \mathrm{mm}^{2}\right)$ \\
\hline
\end{tabular}

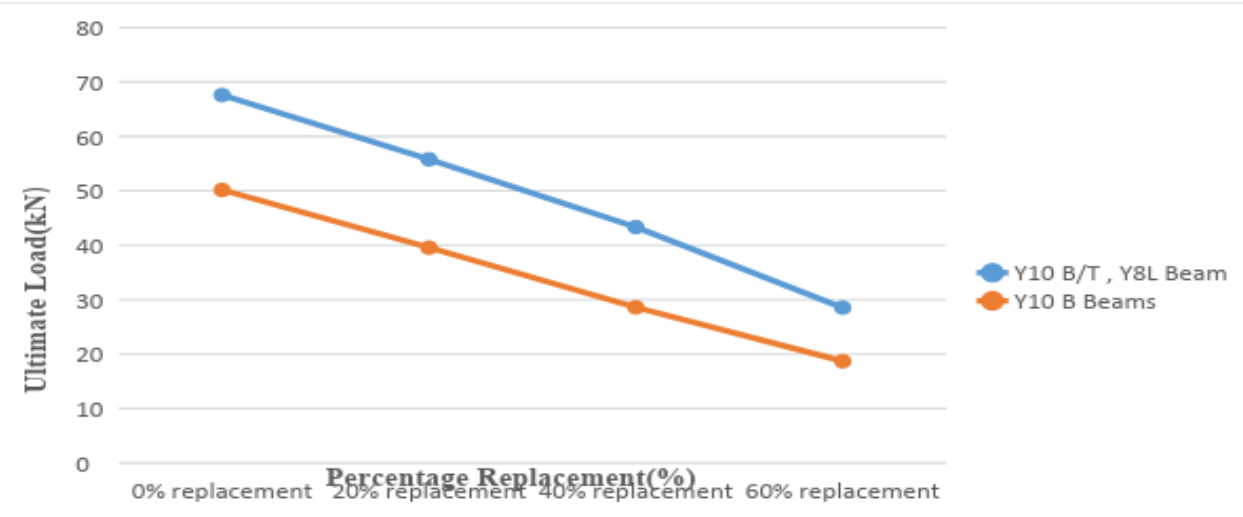

Figure 6: Effect of percentage increase of PKS $A$ with ultimate load of beams

Table 9: Experimental and estimated load capacity for beams

\begin{tabular}{|c|c|c|c|}
\hline \multirow{2}{*}{ Beam ID } & Experimental Load & Compressive Strength $\left.\mathbf{f}_{\text {cu }}\right)$ & Estimated Load (BS code 8110) \\
\cline { 2 - 4 } & $\mathrm{P}_{\text {AUL }}(\mathrm{kN})$ & $\left(\mathrm{N} / \mathrm{mm}^{2}\right)$ & $\mathrm{P}_{\text {EUL }}(\mathrm{kN})$ \\
\hline $\mathrm{B} 1_{\mathrm{NCW}}$ & 50.16 & 10.42 & 22.29 \\
\hline $\mathrm{B} 2_{\mathrm{NCS}}$ & 67.60 & 10.42 & 53.17 \\
\hline $\mathrm{B} 3_{\mathrm{PKW}}$ & 39.57 & 8.39 & 16.48 \\
\hline $\mathrm{B} 4_{\mathrm{PKS}}$ & 55.79 & 8.39 & 50.45 \\
\hline $\mathrm{B} 5_{\mathrm{PKW}}$ & 28.59 & 7.44 & 12.85 \\
\hline $\mathrm{B} 6_{\mathrm{PKS}}$ & 43.35 & 7.44 & 49.17 \\
\hline $\mathrm{B} 7_{\mathrm{PKW}}$ & 18.70 & 7.12 & 11.17 \\
\hline $\mathrm{B} 8_{\mathrm{PKS}}$ & 28.55 & 7.12 & 48.75 \\
\hline
\end{tabular}


From Table 9, the experimental load for B2 $2_{\mathrm{NCS}}$ beam is $21 \%$ higher than the estimated load. While the experimental load at 20\% replacement for B4PKs beam was $9.57 \%$ higher than the estimated load. However the experimental load for B6 PKs and B8PKs beams were $11.8 \%$ and $41.4 \%$ lower than the estimated load.

For beams without shear reinforcement, the $\mathrm{B} 1_{\mathrm{NCW}}$ beam was $125 \%$ higher than the estimated load. While for the $\mathrm{B} 33_{\mathrm{PKW}}, \mathrm{B} 5 \mathrm{PKW}$, and $\mathrm{B} 7 \mathrm{PKW}$ the experimental load was $140 \%, 122.5 \%$ and $67.4 \%$ higher than the estimated load respectively.

\subsection{Deflection Characteristics of Beams}

Table 10 presents the deflection of the beams. From Table 10, the beam deflection depends on the ultimate load, composition of the aggregates and the shear reinforcement.

Table 10: Deflection of PKSC and NWC Beams

\begin{tabular}{|c|c|c|}
\hline Beams ID & Load & Deflection \\
\hline & $(\mathrm{kN})$ & $(\mathrm{mm})$ \\
\hline B1 $1_{\text {NCW }}$ & 50.16 & 6.0 \\
\hline B2 NCS $_{\text {B }}$ & 67.60 & 7.0 \\
\hline B PKW $_{\text {PKS }}$ & 39.57 & 5.0 \\
\hline B $5_{\text {PKW }}$ & 55.79 & 6.5 \\
\hline B6 PKS $_{\text {B }}$ & 28.59 & 4.5 \\
\hline B $8_{\text {PKS }}$ & 43.35 & 6.0 \\
\hline & 18.70 & 2.8 \\
\hline
\end{tabular}

From Figure 7, it can be seen that the higher the percentage of PKSA in the reinforced concrete beam, lower the ultimate load, and hence the deflection.

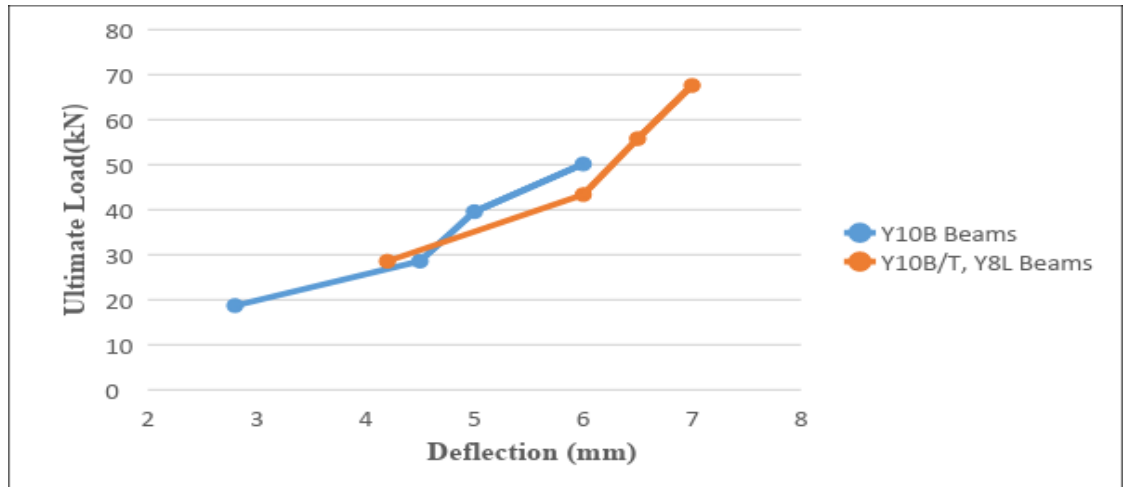

Figure 7: Load-Deflection graph for PKSC and NWC Beams

\subsection{Influence of percentage replacement of PKSA with NWCA and shear reinforcement}

From figures $8, \mathrm{~B} 1_{\mathrm{NCW}}, \mathrm{B} 3_{\mathrm{PKW}}, \mathrm{B} 5_{\mathrm{PKW}}$ and $\mathrm{B} 7_{\mathrm{PKW}}$ are beams without shear reinforcement, with $0 \%, 20 \%, 40 \%$ and $60 \%$ partial replacement of NWA with PKSA respectively. The ultimate loads are, $50.16 \mathrm{kN}, 39.57 \mathrm{kN}, 28.59 \mathrm{kN}$ and $18.70 \mathrm{kN}$ 
respectively. These results show that there is reduction in the ultimate load by $21.11 \%$, $43.00 \%$, and $62.72 \%$ for beams $\mathrm{B} 3 \mathrm{PKW}_{\mathrm{PK}}, \mathrm{B} 5 \mathrm{PKW}$ and $\mathrm{B} 7 \mathrm{PKW}_{\mathrm{N}}$, when compared with $\mathrm{B} 1_{\mathrm{NCW}}$, with $0 \%$ PKSA.

Also from figures 9, B21 $1_{\mathrm{NCS}}, \mathrm{B} 4_{\mathrm{PKS}}, \mathrm{B} 6 \mathrm{PKs}$ and $\mathrm{B} 8 \mathrm{PKs}$ are beams with shear reinforcement, with $0 \%, 20 \%, 40 \%$ and $60 \%$ partial replacement of NWA with PKSA respectively. The ultimate loads are, $67.60 \mathrm{kN}, 55.79 \mathrm{kN}, 43.35 \mathrm{kN}$ and $28.55 \mathrm{kN}$ respectively. These results show that there is reduction in the ultimate load by $17.47 \%$, $35.87 \%$, and $57.77 \%$ for beams B4 $4_{\text {PKS }}$, B6 PKS $_{\text {and }}$ B 8 PKS, when compared with $\mathrm{B} 2_{\mathrm{NCS}}$, with $0 \%$ PKSA.

From the above, it can be seen that there is general increase in ultimate load with provision of shear reinforcement at $200 \mathrm{~mm}$ spacing. For example, there is $34.77 \%$ increase of ultimate load of beam $\mathrm{B} 2_{\mathrm{NCS}}$ over the ultimate of $\mathrm{B} 1_{\mathrm{NCW}}$, by the provision of shear reinforcement at $200 \mathrm{~mm}$ spacing. Also due to provision of shear reinforcement at $200 \mathrm{~mm}$ spacing, there is $41.00 \%, 51.63 \%$ and $52.67 \%$ for beams $\mathrm{B} 4_{\mathrm{PKS}}$ over $\mathrm{B} 3_{\mathrm{PKW}}$, B6PKs over B5PKW and B8PKS over B7 PKW respectively.

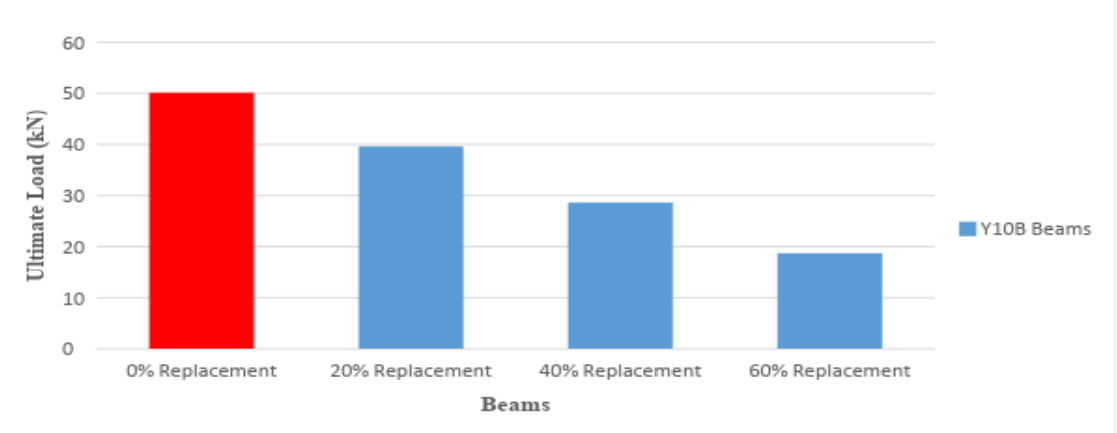

Figure 8: Ultimate loads decrease in beams (without shear) with increasing \% content of PKS A.

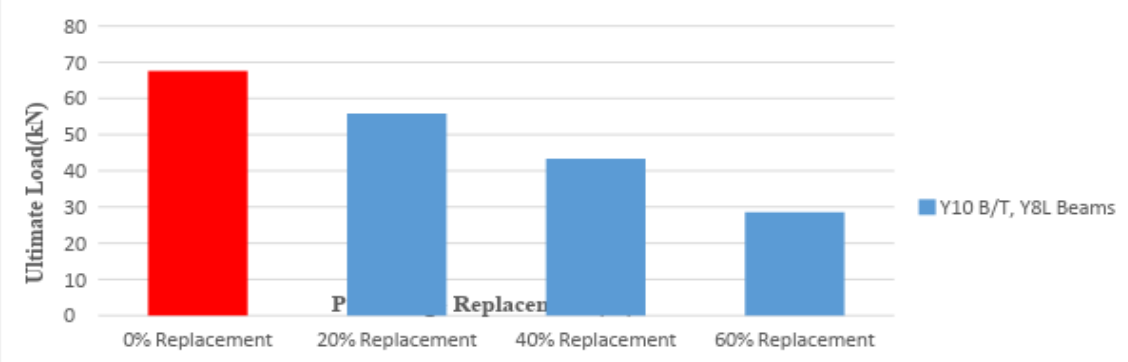

Figure 9: Ultimate loads decrease in beams (with shear) with increasing \% content of PKS A.

\section{Conclusion}

The following conclusions are made from the results and the analysis thereof: 1. There is general decrease in the ultimate load the partial replacement of PKSA increases. 
2. There is general increase in the ultimate load with the provision of shear reinforcement.

3. There is decrease in the percentage reduction of ultimate load with increase in the partial replacement of NWA with PKSA.

4. For beams B4PKs and B6PKs with shear reinforcement of $200 \mathrm{~mm}$ spacing, there is reduction in the ultimate load by $17.47 \%$ and $35.87 \%$ when compared with beam $\mathrm{B} 2{ }_{\mathrm{NCS}}$, with $0 \%$ PKSA and shear reinforcement at $200 \mathrm{~mm}$ spacing. This percentage reduction in the ultimate load can be reduced by the use higher concrete grade and by reducing the spacing of the shear reinforcement, so that such concrete mix can be used for structural purposes, especially in the low cost housing units.

\section{Recommendation for Future Research}

Research should be conducted on the effects of cement grade, concrete grade and shear reinforcements spacing on the ultimate load of PKS reinforced concrete beams.

\section{References}

Abdullah, A. A. A. (1996), Palm oil shell aggregate for lightweight concrete. Waste material used in concrete manufacturing, Noyes Publication, pp. 624-636.

Adama Andrew Y., Yinusa A. Jimoh and Stephen S. Kolo (2013). Effect of Locust Bean Pod Ash on Compaction Characteristics of Weak Sub Grade Soils. International Journal of Engineering Science Invention, Vol. 2, Issue 1, Pp. 25-30.

Adesanya, D.A., and Raheem, A.A. (2009). A study of the Workability and Compressive Strength Characteristics of Corn Cob Ash Blended Cement Concrete. Construction and Building Materials, Vol. 23, Issue 3, Pp. 311 - 317.

Akinwumi, I.I., Aidomojie, O.I. (2015). Effect of Corncob Ash on the Geotechnical Properties of Lateritic Soil Stabilized with Portland Cement. International Journal of Geomatics and Geosciences, Vol. 5, No. 3.

Alengaram, U.J., Jumaat, M.Z. and Mahmud, H. (2008), Influence of cementitious materials and aggregate content on compressive strength of palm kernel shell concrete, Journal of Applied Sciences, Vol. 8(18), pp. 3207-3213.

Aslam, M., Shafigh, P., and Jumaat, M.Z. (2017). High Strength Lightweight Aggregate Concrete using Blended Coarse Lightweight Aggregate Origin from Palm Oil Industry. Sains Malaysiana, Vol. 46, Issue 4, Pp. $667-675$.

BS 882, (1992), Specification for aggregates from natural sources for concrete, British Standards Institution, London, UK.

BS EN 197-1, (2000), Cement - Part 1: Composition, specifications and conformity criteria for common cements, British Standard Institution, London, UK.

BS EN 12350-2. (2009). Testing fresh concrete- Part 2: Slump Test. British Standard Institution, London, UK.

BS EN 12390-3. (2009). Testing hardened concrete- Part 3: Compressive strength of test specimens, British Standard Institution, London, UK.

BS EN 12390-5 (2000), Testing hardened concrete- Part 5: Flexural strength of test specimens, British Standard Institution, London, UK.

BS EN 12390-7. (2000). Testing hardened concrete- Part 7: Density of Hardened Concrete. British Standard Institution, London, UK.

Busari, A., Oyedepo, J., Ofuyatan, O., Nurain, S., Ajayi, S., and Oti, M.N. (2018). Sustainability in Road Construction: Using Bamboo Straw Ash to Improve the Index Properties of Lateritic Soil. European Journal of Sustainable Development, Vol. 7, Issue 1, Pp. 89 - 97. 
Chai, L.J., Shafigh, P., Mahmud, H., and Aslam, M. (2017). Effect of Substitution of Normal Weight Coarse Aggregate with Oil-Palm-Boiler Clinker on Properties of Concrete. Sains Malaysiana, Vol. 46, Issue 4, Pp. $645-653$.

Chungsangunist, T., Gheewla, H., and Patumsawad, S., (2009). Emission Assessment of Rice Husk Combustion for Power Production. World Academy of Science, Engineering and Technology Journal. Vol. 53, Pp $1070-1075$.

Dwivedi, V.N., Singh, N.P., Das, S.S.., and Singh, N.B. (2006). A New Pozzolanic Material for the Cement Industry: Bamboo Leaf Ash. International Journal of Physical Sciences, Vol. 1 (3), Pp. 106 - 111.

Ndoke, P. N. (2006), Performance of palm kernel shells as a partial replacement for coarse aggregate in asphalt concrete, Leonardo Electronic Journal of Practices and Technologies, Vol. 5(9), pp. 145-52.

Neville, A.M. (1981), Properties of Concrete, 3rd Ed., Pitman, New York.

Newman, J., and Owen, P. (2003). Properties of Lightweight Concrete. In J. Newman and B.S. Choo (Eds.), Advanced Concrete Technology: Processes (pp. 2/3). Elsvier, Butterworth Heinemann, London.

Olonode, K.A. (2010). Prospect of Agro-By-Products as Pozzolans in Concrete for Low-Cost Housing Delivery in Nigeria. Proceedings of the International Conference of the Obafemi Awolowo University, Faculty of Technolgy. Vol. 1, Pp. $217-221$.

Osei, D.Y. and E.N. Jackson (2012).Experimental Study on Palm Kernel Shells as Coarse Aggregate in Concrete. International Journal of Scientific and Engineering Research, vol. 3, issue 8, pp.1-6.

Salau, M.A., Ikponmwosa, E.E., and Olonode, K.A. (2012). Structural Strength Characteristics of Cement/Cassava Peel Ash Blended Concrete. Journal of Civil and Environmental Research. IISTE. Vol. 2, No. 10****

Shafigh, P., Jumaat, M. Z., Mahmud, H. B. and Anjang, N. A. H. (2012), Lightweight concrete made from crushed oil palm shell: Tensile strength and effect of initial curing on compressive strength, Construction and Building Materials, Vol. 27, pp. 252-258.

Short, A, and W. Kinniburgh, (1978), Lightweight Concrete, 3rd ed. London: Applied Science. 